\title{
Phytochemical and In Vitro Genotoxicity Studies of Standardized Ficus deltoidea var. kunstleri Aqueous Extract
}

\author{
Hussin Muhammad *(D), Maizatul Hasyima Omar, Elda Nurafnie Ibnu Rasid (D), Shazlan Noor Suhaimi (D, \\ Farah Huda Mohkiar, Lau Mei Siu and Norizah Awang
}

\author{
Herbal Medicine Research Centre, Institute for Medical Research, National Institutes of Health, Ministry of \\ Health, Malaysia, Level 5, Block C7, No. 1, Jalan Setia Murni U13/52, Seksyen U13, Setia Alam, Shah Alam 40170, \\ Selangor, Malaysia; maizatul.hasyima@moh.gov.my (M.H.O.); elda@moh.gov.my (E.N.I.R.); \\ shazlannoor@moh.gov.my (S.N.S.); farahhuda.m@moh.gov.my (F.H.M.); laums@moh.gov.my (L.M.S.); \\ norizah@moh.gov.my (N.A.) \\ * Correspondence: hussin.m@moh.gov.my
}

check for updates

Citation: Muhammad, H.; Omar, M.H.; Rasid, E.N.I.; Suhaimi, S.N.; Mohkiar, F.H.; Siu, L.M.; Awang, N. Phytochemical and In Vitro Genotoxicity Studies of Standardized Ficus deltoidea var. kunstleri Aqueous Extract. Plants 2021, 10, 343.

https://doi.org/

10.3390/plants10020343

Received: 15 December 2020

Accepted: 19 January 2021

Published: 11 February 2021

Publisher's Note: MDPI stays neutral with regard to jurisdictional claims in published maps and institutional affiliations.

Copyright: (c) 2021 by the authors. Licensee MDPI, Basel, Switzerland. This article is an open access article distributed under the terms and conditions of the Creative Commons Attribution (CC BY) license (https:/ / creativecommons.org/licenses/by/ $4.0 /)$.

\begin{abstract}
The present study was carried out to assess the genotoxicity potential of Ficus deltoidea var. kunstleri aqueous extract (FDAE) using standard in vitro assays. The DNA damage of V79B cells was measured using the alkaline comet assay treated at $0.1 \mathrm{mg} / \mathrm{mL}$ (IC10) and $0.3 \mathrm{mg} / \mathrm{mL}$ (IC25) of FDAE together with positive and negative controls. For in vitro micronucleus assay, the V79B cells were treated with FDAE at five different concentrations $(5,2.5,1.25,0.625$, and $0.3125 \mathrm{mg} / \mathrm{mL})$ with and without S9 mixture. The bacteria reverse mutation assay of FDAE was performed on Salmonella typhimurium strains TA98, 100, 1535, 1537, and Escherichia coli strain WP2uvrA using pre-incubation method in the presence or in the absence of an extrinsic metabolic system (S9 mixture). FDAE at 0.1 and $0.3 \mathrm{mg} / \mathrm{mL}$ significantly increased DNA damage in both comet tail and tail moment $(p<0.05)$. No significant changes were detected in the number of micronucleated cell when compared to control. Tested at the doses up to $5000 \mu \mathrm{g} /$ plate, the FDAE did not increase the number of revertant colonies for all strains. In conclusion, further investigation needs to be conducted in animal model to confirm the non-genotoxicity activities of FDAE.
\end{abstract}

Keywords: Ficus deltoidea; genotoxicity; Salmonella typhimurium; alkaline comet assay; micronucleus

\section{Introduction}

Medicinal herbs have been utilized as a complementary and alternative medicine for many years in which it has gained widespread popularity throughout the world in treating diseases and improving healthy life in human-beings [1,2]. Herbs, herbal preparations, herbal materials, or finished herbal products are the herbal medicines that contain active ingredients [1]. Herbal products are generally not prepared according to the standard procedures of formulation as well as their evaluation of safety; hence, the herbal toxicity has become a major concern due to their wide use [3]. Furthermore, overutilization of natural materials without a proper toxicity data could potentially act as a carcinogen or mutagen [4]. Therefore, it is crucial to perform the safety assessment of herbal medicines particularly on their effects on genetic materials which may leads to cell mutation.

Ficus deltoidea (family: Moraceae) or locally known as "Mas Cotek" is one of the most common plants used in herbal based products development in Malaysia. However, it is native and widely distributed in other Southeast Asia countries including Thailand and Indonesia since the past few decades [5]. F. deltoidea is an epiphytic shrub which has been traditionally used for relieving headache, treating cold, rheumatism, and to strengthening the uterus after birth [6,7]. Most of the benefits are contributed by the flavonoids found in the plants. Scientifically, flavonoids have shown various pharmacological properties such as anti-carcinogenic, anti-mutagenic, anti-inflammatory, anti-viral, and anti-oxidant activities [8,9], though little is known about their safety and potentially detrimental toxic 
effects which might take place if taken in large doses for a short period or a long period of time [10]. Notwithstanding the widespread use of F. deltoidea plant in traditional medicine, limited data on genotoxicity effects particularly on variety kunstleri is available.

To evaluate the genotoxic potential of $F$. deltoidea aqueous extract (FDAE), in vitro testing through alkaline comet assay, micronucleus and Salmonella typhimurium/reverse mutation assay were performed in the present study.

\section{Results}

\subsection{Phytochemical Analysis}

The analysis of aqueous extract of $F$. deltoidea by reverse phase HPLC (RP-HPLC-ESI) revealed that flavonoids were the major class of phenolics in FDAE. Fifteen flavonoids were characterized. The obtained based peak chromatogram is illustrated in Figure 1. The phenolic compounds present in the FDAE are summarized in Table 1, with their formula, name, absorbance spectrum, calculated $\mathrm{m} / \mathrm{z}$, MS fragments, and migration.

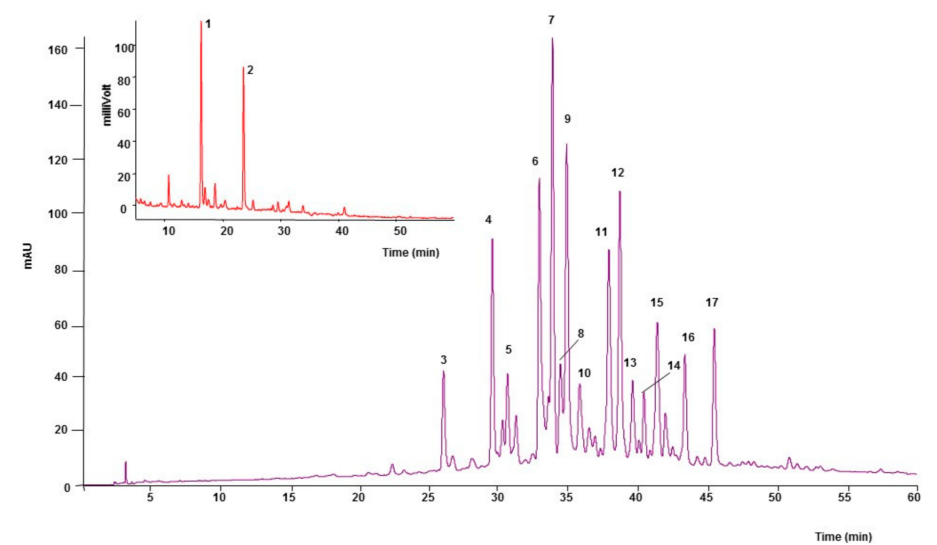

Figure 1. HPLC-ESI/MS profile of F. deltoidea aqueous extract (FDAE), analyzed by gradient phase at $365 \mathrm{~nm}$ (purple) and florescence detector (red).

Table 1. Tentative identification of phenolic compounds in F. deltoidea extract determined by HPLC-ESI.

\begin{tabular}{|c|c|c|c|c|c|}
\hline Peak & $t_{R}$ & $\lambda_{\max }$ & Compound & {$[\mathrm{M}-\mathrm{H}]^{-}(\mathrm{m} / \mathrm{z})$} & MS2 Fragments Ions $(\mathrm{m} / \mathrm{z})$ \\
\hline 1 & 16.2 & 280 & $(+)$-Catechin & 289 & 245,179 \\
\hline 2 & 23.5 & 280 & (-)-Epicatechin & 289 & $245,205,179$ \\
\hline 3 & 25.9 & 350 & Luteolin-6-8-C-diglucoside (Lucenin-2) & 609 & $489,519,399$ \\
\hline 4 & 29.4 & 340 & Apigenin-6, 8-C-diglucoside (Vicenin-2) & 593 & $473,503,353$ \\
\hline 5 & 30.5 & 345 & Unidentified & 517 & $385,205,222$ \\
\hline 6 & 32.8 & 335 & $\begin{array}{l}\text { Apigenin-6-C-ara-8- } C \text {-glucoside } \\
\text { (Isoschaftoside) }\end{array}$ & 563 & $473,443,503$ \\
\hline 7 & 33.7 & 335 & $\begin{array}{c}\text { Apigenin-6-C-glu-8- } C \text {-arabinoside } \\
\text { (Schaftoside) }\end{array}$ & 563 & $473,503,443$ \\
\hline 8 & 34.3 & 345 & Luteolin 6-C-glucoside (Isoorientin) & 447 & $327,357,369$ \\
\hline 9 & 34.8 & 325 & Unidentified & 565 & $444,474,443$ \\
\hline 10 & 35.7 & 335 & Luteolin-8-C-diglucoside (Orientin) & 447 & $327,429,357$ \\
\hline 11 & 37.8 & 335 & Apigenin -8-C-glucoside (Vitexin) & 431 & $311,341,283$ \\
\hline 12 & 38.6 & 335 & Apigenin-6-C-pent-8-C-glucoside & 563 & $443,473,353$ \\
\hline 13 & 39.5 & 335 & Apigenin-6-C-pentosyl-8-C-pentoside & 533 & $443,473,515$ \\
\hline 14 & 40.3 & 335 & Apigenin-6-C-pentosyl-8-C-pentoside & 533 & $443,473,515$ \\
\hline 15 & 41.3 & 345 & Apigenin 6-C-glucoside (Isovitexin) & 431 & $311,341,413$ \\
\hline 16 & 43.3 & 335 & Unidentified & 535 & $443,474,516$ \\
\hline 17 & 45.4 & 335 & Chrysin-6-8-C-diglucoside & 577 & $457,487,353$ \\
\hline
\end{tabular}




\subsection{MTS Cytotoxicity Assay}

The potency of cell growth inhibition for FDAE on V79B cells was assayed. The cytotoxicity effect of the extract was measured after $24 \mathrm{~h}$ of exposure to a serial range of concentrations using MTS assay. The growth inhibitory effects were expressed as IC10 and IC25 (Figure 2). The toxic effect of FDAE exhibited in a dose-dependent manner and at a concentration of $5 \mathrm{mg} / \mathrm{mL}$ extract, the cell viability was $3.3 \pm 4.1 \%$ relative to untreated controls. The growth inhibitory effect for IC10 and IC25 value were 0.1 and $0.3 \mathrm{mg} / \mathrm{mL}$, respectively.

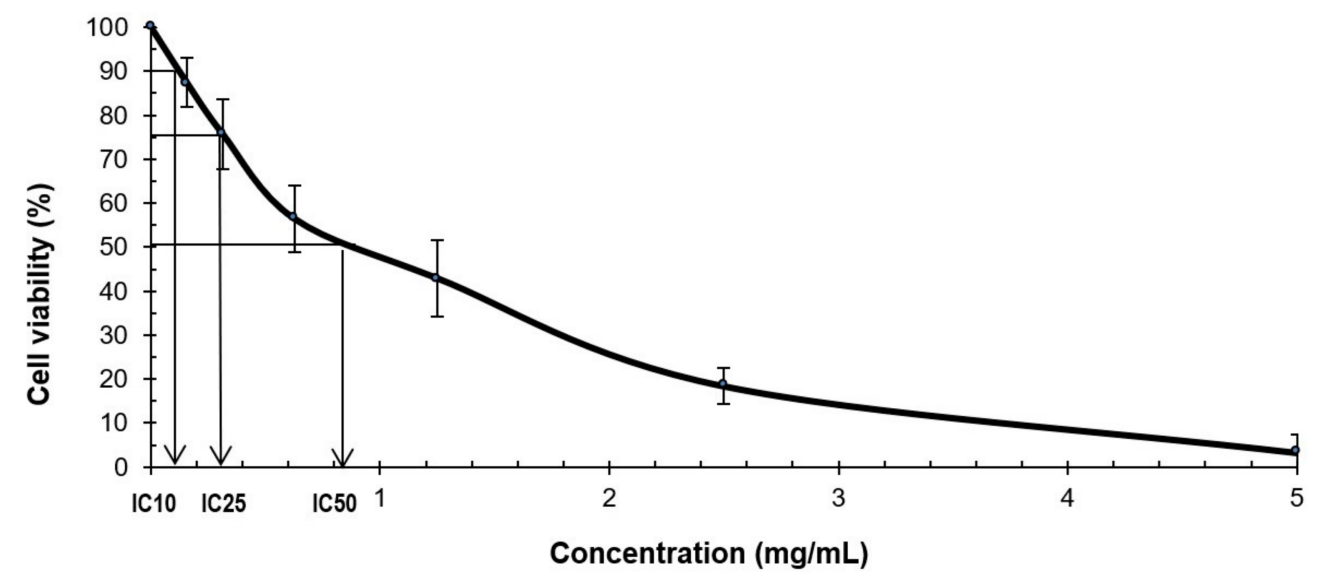

Figure 2. Cytotoxic effect of FDAE was demonstrated following $24 \pm 2 \mathrm{~h}$ treatment on V79B cells. Data are expressed as percentage of viability compared to negative control (without any treatment). IC10: concentration of Test Item that produce 10\% inhibition of cell viability. IC25: concentration of Test Item that produce $25 \%$ inhibition of cell viability. IC50: concentration of Test Item that produce $50 \%$ inhibition of cell viability.

\subsection{Alkaline Comet Assay}

The DNA percentage in the comet tail and tail moment were used to measure the potential DNA damage caused by FDAE. The extract induced DNA damage by a significant increase in both \% of DNA in tail and tail moment $(p<0.05)$ at concentrations of $0.1 \mathrm{mg} / \mathrm{mL}$ and $0.3 \mathrm{mg} / \mathrm{mL}$, respectively, as shown in Figure 3.

\subsection{In Vitro Micronucleus Assay}

In the dose finding test, there were no precipitation of FDAE for all concentration observed in plates after treatment period. The FDAE was not cytotoxic at up to the highest concentration $(5 \mathrm{mg} / \mathrm{mL})$ in the presence and absence of S9 mixture, thus this dose was selected as the highest concentration for main experiment. Treatment with FDAE at 1.25, 2.5 , and $5 \mathrm{mg} / \mathrm{mL}$ did not show a concentration-related increase in the percentage of micronucleated cells in both the absence and presence of metabolic activation compared to negative control. Figure 4 shows the percentage of micronucleated cells.

\subsection{Salmonella typhimurium/Microsome Assay}

A preliminary test was carried out in all tester strains and neither reductions of the number of the revertants or alterations of the auxotrophic bacterial grown were apparent up to the highest dose tested $(5000 \mu \mathrm{g} / \mathrm{plate})$. No dose-dependent increase in revertant colonies or bacterial toxicity were observed in the dose finding test at concentrations of FDAE up to $5000 \mu \mathrm{g} /$ plate in the presence or absence of metabolic activation. The main experiment was performed in a similar manner at concentrations ranging from 313 to $5000 \mu \mathrm{g} /$ plate. Data are summarized in Tables 2 and 3. No bacterial toxicity was observed at any dose tested. The positive controls for each strain resulted in the expected increase in the number of revertant colonies. 
a

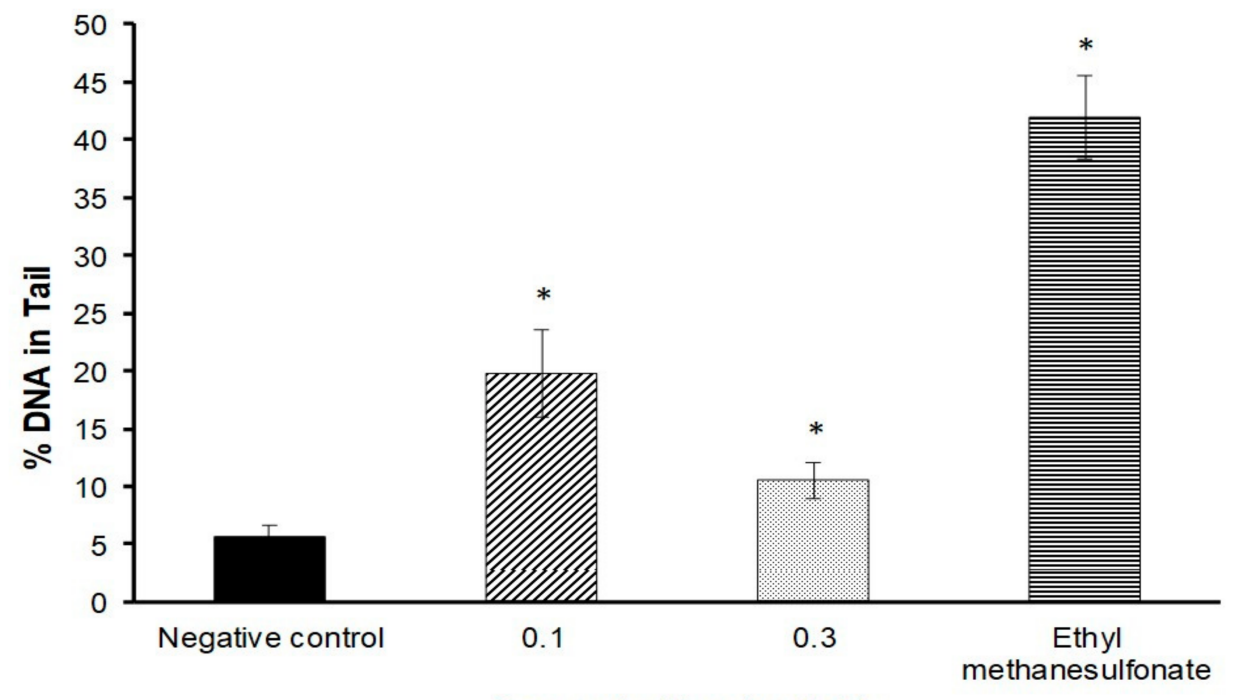

Concentration $(\mathrm{mg} / \mathrm{mL})$

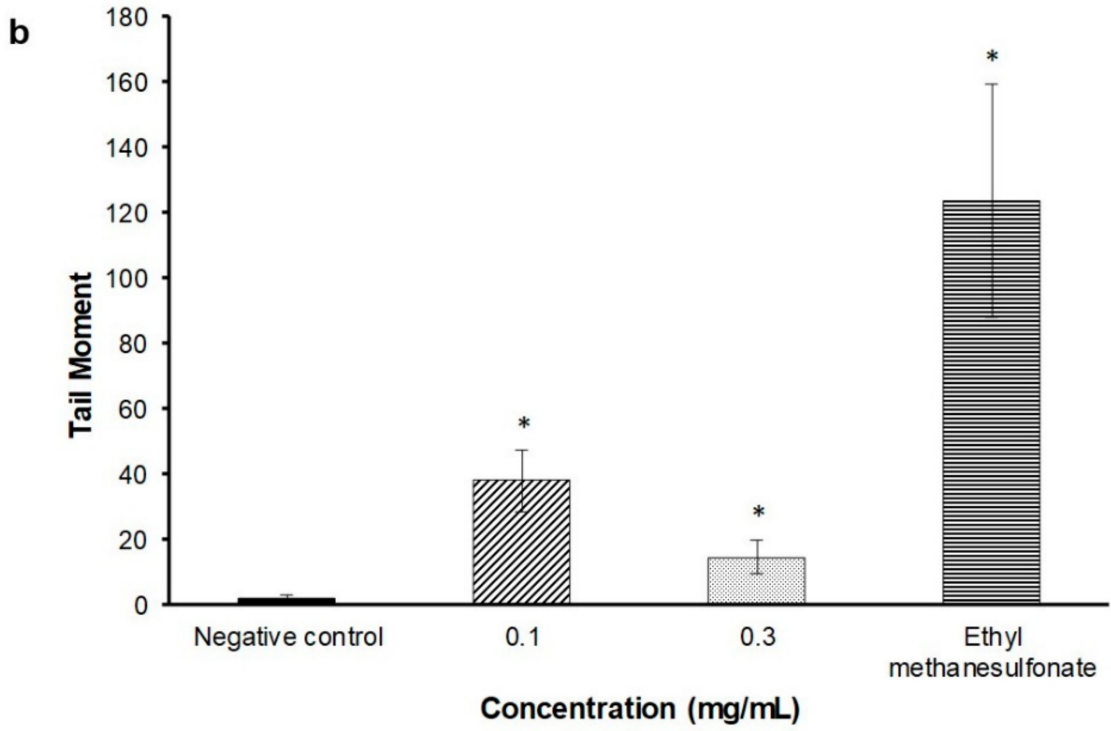

Figure 3. The DNA damage induction in V79B cells measured by alkaline comet assay after cells were treated either with FDAE or positive control (Ethyl methanesulfonate) for $2 \mathrm{~h}$. DNA damage is expressed as (a): \% DNA in tail and (b): tail moment. Data was expressed as mean \pm SEM. * is where $p$ value is $<0.05$ as compared to negative control. 
a

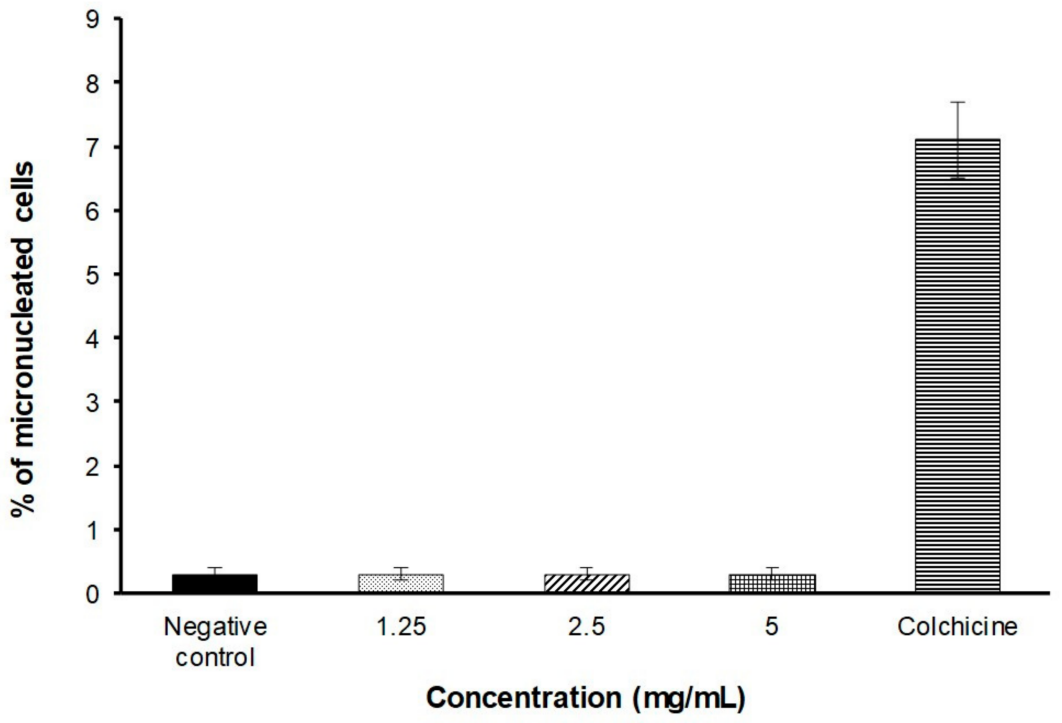

b

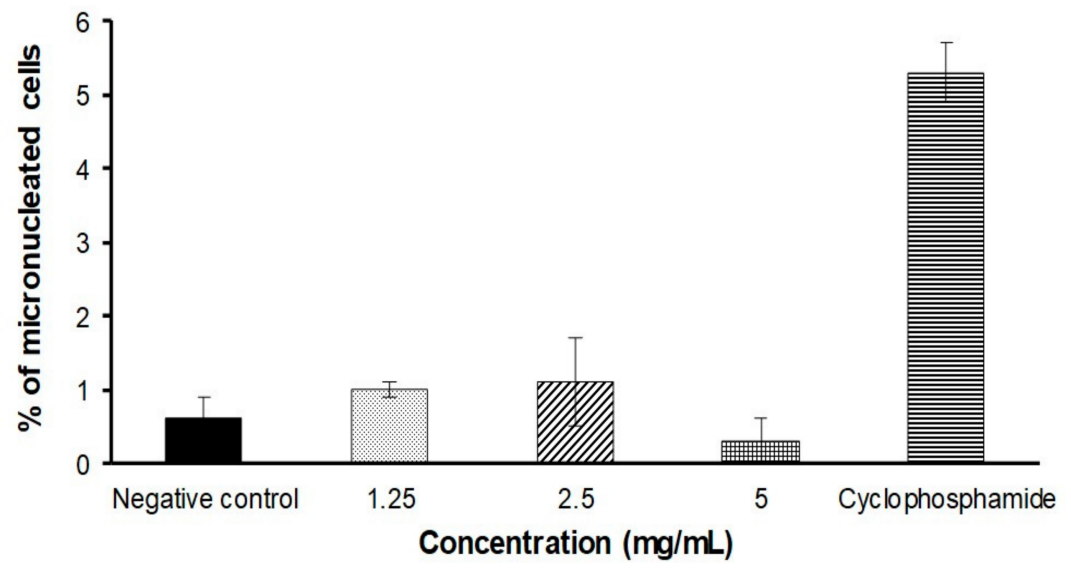

Figure 4. Percentage of micronucleated cells induced by different concentrations of FDAE or positive controls treated on V79B cells for $3 \mathrm{~h}$ with (a) and without (b) the presence of S9 metabolic activation. Data was expressed as mean \pm SEM.

Table 2. Mutagenicity testing of FDAE in the Salmonella typhimurium/microsome assay without S9 metabolic activation on TA100, TA1535, TA98, TA1537, and WP2uvrA tester strains.

\begin{tabular}{cccccc}
\hline \multirow{2}{*}{ Dose $(\boldsymbol{\mu}$ /Plate) } & \multicolumn{4}{c}{ Number of Revertants (Mean \pm SD) } \\
\cline { 2 - 5 } & \multicolumn{2}{c}{ Base-Pair Substitution Type } & \multicolumn{1}{c}{ Frameshift Type } \\
\cline { 2 - 5 } & $136 \pm 10$ & $13 \pm 2$ & $57 \pm 5$ & $21 \pm 4$ & $8 \pm 2$ \\
0 & $145 \pm 12$ & $14 \pm 1$ & $53 \pm 3$ & $21 \pm 1$ & $9 \pm 2$ \\
313 & $135 \pm 5$ & $10 \pm 2$ & $58 \pm 4$ & $20 \pm 3$ & $9 \pm 2$ \\
625 & $130 \pm 8$ & $11 \pm 3$ & $48 \pm 4$ & $19 \pm 1$ & $11 \pm 2$ \\
1250 & $134 \pm 11$ & $10 \pm 1$ & $55 \pm 2$ & $23 \pm 4$ & $10 \pm 2$ \\
2500 & $166 \pm 7$ & $12 \pm 1$ & $53 \pm 3$ & $25 \pm 2$ & $11 \pm 3$ \\
5000 & $627 \pm 6$ & $558 \pm 6$ & $180 \pm 7$ & $539 \pm 4$ & $608 \pm 4$ \\
\hline
\end{tabular}

Values are mean \pm SD of 3 plates. Dose 0-negative control: $100 \mu \mathrm{L}$ pure water; Positive control: for TA100 and TA1535, $\mathrm{NaN}_{3}(0.5 \mu \mathrm{g} /$ plate); WP2uvrA, MMC (1 $\mu \mathrm{g} /$ plate); TA98, 2-NF (1 $\mu \mathrm{g} / \mathrm{plate})$ and TA1537, ICR-191 (1 $\mu \mathrm{g} /$ plate). 
Table 3. Mutagenicity testing of FDAE in the Salmonella typhimurium/microsome assay with S9 metabolic activation on TA100, TA1535, TA98, TA1537 and WP2uvrA tester strains.

\begin{tabular}{cccccc}
\hline \multirow{2}{*}{ Dose $(\mu \mathrm{g} /$ Plate) } & \multicolumn{4}{c}{ Number of Revertants (Mean \pm SD) } \\
\cline { 2 - 5 } & \multicolumn{2}{c}{ Base-Pair Substitution Type } & \multicolumn{1}{c}{ Frameshift Type } \\
\cline { 2 - 5 } & $162 \pm 6$ & $17 \pm 3$ & $60 \pm 4$ & $24 \pm 4$ & $10 \pm 1$ \\
0 & $151 \pm 10$ & $15 \pm 2$ & $63 \pm 4$ & $30 \pm 4$ & $11 \pm 2$ \\
313 & $145 \pm 12$ & $14 \pm 2$ & $63 \pm 2$ & $28 \pm 2$ & $12 \pm 2$ \\
625 & $158 \pm 5$ & $15 \pm 2$ & $53 \pm 4$ & $32 \pm 3$ & $10 \pm 2$ \\
1250 & $142 \pm 3$ & $14 \pm 1$ & $57 \pm 5$ & $28 \pm 2$ & $12 \pm 2$ \\
2500 & $149 \pm 6$ & $14 \pm 3$ & $62 \pm 8$ & $29 \pm 2$ & $11 \pm 1$ \\
5000 & $519 \pm 4$ & $165 \pm 4$ & $192 \pm 4$ & $232 \pm 6$ & $183 \pm 3$ \\
\hline
\end{tabular}

Values are mean \pm SD of 3 plates. Dose 0-negative control: $100 \mu \mathrm{L}$ pure water; Positive control: 2AA for all

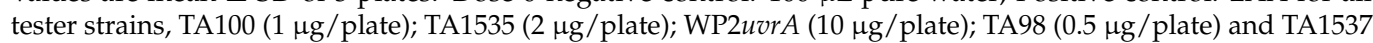
$(2 \mu \mathrm{g} /$ plate $)$.

\section{Discussion}

Despite the keen interest of traditional herbal medicine being used to treat various diseases, the toxicity and genotoxicity information of these herbal preparations are still lacking. Majority believes that products originated from natural sources are safe and they should devoid of toxicity. Therefore, an assessment of genotoxicity of leaves of $F$. deltoidea aqueous extract is required to ensure the safety of the F. deltoidea. In the current work, the mutagenic, and/or genotoxic of FDAE were studied with various assays.

Polyphenol-rich plants are often attributed with their potent antioxidant activities which are beneficial to human health. Flavonoids are phenolics found in the vegetables and plant-derived products such as flowers, fruits, roots bark, stems, grains, wine, and tea [11]. Knowledge on the flavonoids content of plant-based foods is paramount for better understanding in their role in plant physiology as well as human health. Identification of these compounds will determine their therapeutic value.

Our finding showed that flavonoids and phenolic compounds were identified in FDAE as reported in the previous study [12]. This study revealed FDAE consist of catechin and epicatechin, which are powerful antioxidant together with the presence of vitexin and apigenin, which have been demonstrated to have antioxidant with antigenotoxicity properties $[13,14]$.

The presence of phenolic and flavonoid compounds has received a great attention on their free radical scavenging activities as a cellular defense mechanism to suppress the toxicity and genotoxicity of various mutagens in life organism. However, besides their beneficial effects, various studies have been reported about the cellular toxicity effects of flavonoids as a result of their pro-oxidant activities [15]. The cytotoxicity effects of FDAE were measured in V79B cell line by the MTS assay. Results of the present study clearly showed that the FDAE reduced the cell viability at up to the highest concentration in dose dependent manner. Similar cytotoxicity activity was observed in the methanolic extracts of F. deltoidea against human leukemic HL-60 cell lines as the cellular DNA fragmentation was revealed through microscopic evaluation on dead cells [16]. The presence of polyphenolic compounds in FDAE could influence cell function by modulating cell signaling, altering proliferation and inducing cytotoxicity in cells and requires further investigations.

The genotoxicity effect of FDAE was further evaluated at gene level based on DNA fragmentation from alkaline comet assay. This assay uses single-cell nucleus electrophoresis which can detect primary DNA damage expressed as single or double strand breaks [17]. It is based on the quantification of denatured DNA fragments that have migrated out from the cell nucleus during electrophoresis. The positive results obtained from this study indicated that FDAE could induce a direct genotoxic activity to produce DNA-lesions in V78B cells. The mechanisms by which FDAE may interact with DNA are difficult to predict. One possible cause contributing to the positive response observed in this assay could be 
the pro-oxidant activity of catechins found in the extract. It has been demonstrated that polyphenols, including catechins, can act as antioxidants and also as pro-oxidants under certain conditions [18], which induced oxidative damage in vitro studies [19-21]. Moreover, other findings showed that EGCG (epigallocatechin gallate), a predominant component of catechin preparations, induced chromosomal damage in WIL2-NS cells at $100 \mu \mathrm{mol} / \mathrm{L}$ [22] However, whether polyphenols can act as pro-oxidants or antioxidants is likely dependent upon the relative redox-potentials of the in vitro culture conditions. A report by Ogura et al. (2008) [23] indicated that the pro-oxidant activity of catechins in in vitro culture was generated from the ample supply of dissolved oxygen. Other possible mechanism of action that cause DNA damage could be also due to the generation of reactive oxygen species [24] or the inhibition of scavenging enzymes against reactive oxygen species including catalase, superoxide dismutase and glutathione peroxidase [25] which require further investigations to confirm these activities.

In contrast, data from the Salmonella typhimurium/microsome assay provides no evidence of mutagenic potential as no increase of the number of revertant colonies when tested up to the highest dose $(5000 \mu \mathrm{g} /$ plate $)$ over the negative control, either in the presence and the absence of extrinsic metabolic activation, S9. Standard mutagens (2-AA, $\mathrm{NaN}_{3}, \mathrm{MMC}, 2-\mathrm{NF}$ and ICR-191), however, exhibited significant amplified number of revertant colonies in all strains. Similar finding was observed in TA98 and TA100 when tested with standardized methanolic extract of $F$. deltoidea [26]. Negative response was also observed in the study on green tea extract that rich with catechin compound at the highest concentration $(5000 \mu \mathrm{g} /$ plate). These data demonstrate no evidence of potential gene mutagenic effect under the conditions used in this test for FDAE.

To determine whether FDAE causes numerical and structural chromosome changes, an in vitro micronucleus test using V79B cells was conducted. In the present study, no significant increase in the number of micronuclei in any tested dose of FDAE compared with the negative control. These results are also consistent with the study findings of Ogura et al. (2008) [23] which assessed the potential genotoxic effect of a catechin rich tea preparation on ICR mice and Sprague Dawley rats using a bone marrow micronucleus assay. These results have shown that FDAE was not mutagenic in both the absence and presence of metabolic activation towards V79B cells.

\section{Materials and Methods}

\subsection{Plant Materials and Extract Preparation}

F. deltoidea dried leaves were purchased locally from Pahang, Malaysia. Leaves were dried in oven (Memmert, Germany) at $45^{\circ} \mathrm{C}$ for 2 days and ground to a powdered form prior to extraction with water by boiling it for $1 \mathrm{~h}$ before assign through filter paper (Whatman, No.1). Filtrates collected were sprayed dried (Buchi, Switzerland) to form a powder that was further used in the experiments. The powdered aqueous extract of $F$. deltoidea (FDAE) were then analyzed by HPLC with absorbance, fluorescence and mass spectrometric detection to determine the major constituents. The HPLC system employed consisted of Surveyor gradient (Thermo Scientific, CA, USA), comprising of a pumping system, auto sampler, and degasser coupled with photodiode array absorbance (PDA) detector scanning from 200 to $700 \mathrm{~nm}$ controlled by Xcalibur software version 1.3. Separation was carried out using MAX-RP $4 \mu \mathrm{m}, 250 \mathrm{~mm} \times 4.6 \mathrm{~mm} \mathrm{C12}$ reverse phase column (Phenomenex, Torrance, CA, USA) maintained at $40{ }^{\circ} \mathrm{C}$ and eluted at a flow rate of $1.0 \mathrm{~mL} / \mathrm{min}$ with $60 \mathrm{~min}$ gradient from 15 to $50 \%$ methanol in water containing $0.1 \%$ formic acid. After passing through the flow cell of the photodiode array and fluorescence detectors, the column eluate was split and 20\% directed to an LCQ Duo mass spectrometer (Thermo-Finnigan) with an electrospray interface operating in full scan data dependent MS/MS mode from 150 to $1000 \mathrm{amu}$. (+)-Catechin and (-)-epicatechin were identified by fluorescence (FL) detector (Jasco FP-920) at the wavelengths ( $\lambda$ EX/ $\lambda$ EM) 280/315 nm. 


\subsection{MTS Cytotoxicity Assay}

\subsubsection{Cell Culture}

V79B cell is a fibroblast-like morphology cell line originated from Chinese hamster lung. It was obtained from RIKEN Cell Bank, Japan (Resource No: RBRC-RCB2337). Cells were thawed and subcultured in Dulbecco's Modified Eagle Medium (DMEM) supplemented with $10 \%$ Fetal Bovine Serum and 1\% antibiotic/antimycotic solution and incubated in a humidified $\mathrm{CO}_{2}$ incubator at $37 \pm 2{ }^{\circ} \mathrm{C}$. Cells were washed with phosphate buffer solution and harvested by trypsinization using trypsin-EDTA $0.05 \%(w / v)$. The cells suspension was then centrifuged at $1000 \mathrm{rpm}$ for $3 \mathrm{~min}$. The pellet was re-suspended in the culture medium and the cells were counted using the Countess ${ }^{\mathrm{TM}}$ Automated Cell Counter.

\subsubsection{Cytotoxicity Determination}

Six treatment concentrations of $\operatorname{FDAE}(5,2.5,1.25,0.625,0.3125$, and $0.15625 \mathrm{mg} / \mathrm{mL})$ were prepared for the experiment. Culture medium from each well of 96-well plate was discarded and added with $200 \mu \mathrm{L}$ extract at different concentrations and culture medium for negative control. Well without cells were used as blank. The plate was incubated for $24 \pm 2 \mathrm{~h}$ at $37 \pm 2{ }^{\circ} \mathrm{C}$ with $5 \pm 1 \% \mathrm{CO}_{2}$ in $\mathrm{CO}_{2}$ incubator. After $24 \pm 2 \mathrm{~h}$ of incubation, $40 \mu \mathrm{L}$ of MTS reagents was added into each well. The plate was then incubated for about $1 \mathrm{~h}$ at $37 \pm 2{ }^{\circ} \mathrm{C}$ with $5 \pm 1 \% \mathrm{CO}_{2}$ in $\mathrm{CO}_{2}$ incubator. The plate was read at $492 \mathrm{~nm}$ using the ELISA Microplate reader. A concentration against percentage of cell viability graph was plotted. Two cytotoxic concentrations (IC10 and IC25) were selected for the Alkaline Comet assay.

\subsection{Genotoxicity Assays}

\subsubsection{Alkaline Comet Assay}

All culture medium from each well of 96 well plates were discarded and washed with $2 \mathrm{~mL}$ of PBS. Two mL of FDAE (IC10 and IC25), negative control and positive control were pipetted into designated well of 6-well plate. The plate was incubated for $2 \mathrm{~h}$ at $37 \pm 2{ }^{\circ} \mathrm{C}$ and $5 \pm 1 \% \mathrm{CO}_{2}$ in $\mathrm{CO}_{2}$ incubator. After $2 \mathrm{~h}$ of incubation, all culture media was discarded. Cells were washed, trypsinized with $1 \mathrm{~mL}$ of Trypsin-EDTA and $2 \mathrm{~mL}$ of culture medium to neutralize the reaction into each well. Cells were re-suspended and $1 \mathrm{~mL}$ transferred into three different microcentrifuge tubes and centrifuged at $2500 \mathrm{rpm}$ at $4{ }^{\circ} \mathrm{C}$ for $5 \mathrm{~min}$. The supernatant was discarded and $1 \mathrm{~mL}$ of cold PBS was added into each tube and centrifuged again at $2500 \mathrm{rpm}$ at $4{ }^{\circ} \mathrm{C}$ for $5 \mathrm{~min}$. The supernatant was discarded, then $80 \mu \mathrm{L}$ of LMA (low melting agarose) was mixed with the pallet and re-suspended gently. The mixture was then pipetted onto the slide with $100 \mu \mathrm{L}$ solidified NMA (normal melting agarose) and covered with cover slip. The agarose was allowed to solidify on ice for few minutes. The cover slip was removed and slides were immersed into lysis buffer solution containing $1 \% v / v$ Triton $\mathrm{X}-100$ for $1 \mathrm{~h}$ at $2-8{ }^{\circ} \mathrm{C}$. The slides were then transferred onto electrophoresis tank filled with buffer solution and left for $20 \mathrm{~min}$ to permit unwinding of DNA. After $20 \mathrm{~min}$, the electrophoresis process was initiated ( $300 \mathrm{~mA}$ and $25 \mathrm{~V}$ ) for another $20 \mathrm{~min}$. The slides were transferred and washed with neutralization buffer solution every 5 min for 3 times. Then, $40 \mu \mathrm{L}$ of ethidium bromide solution was pipette onto slides and covered with cover slips. The slides were kept overnight at $2-8{ }^{\circ} \mathrm{C}$ and observed under fluorescence microscope. Fifty single cells were analyzed for each slide using Tritek CometScore@ free software. Score for \% DNA in tail and tail moment was collected and transferred into Alkaline Comet Assay Excel Template.

\subsubsection{In Vitro Micronucleus Assay}

The assay was performed according to OECD 487 in vitro Mammalian Cell Micronucleus [27] with minor modifications. Two $\mathrm{mL}$ of V79B cells suspension $\left(5 \times 10^{4}\right.$ cells $\left./ \mathrm{mL}\right)$ were dispensed into designated well of 6-well plate. Cells were incubated for $24 \pm 2 \mathrm{~h}$ at $37 \pm 2{ }^{\circ} \mathrm{C}$ and $5 \% \mathrm{CO}_{2}$ in incubator. After $24 \mathrm{~h}$, the subconfluency and the morphology of the cells were verified. V79B cells were washed with $1 \mathrm{~mL}$ of PBS. Then, $5 \mathrm{~mL}$ of culture 
media containing either $1.25,2.5$, and $5 \mathrm{mg} / \mathrm{mL}$ FDAE, and negative control or positive control (colchicine-without S9 activation and cyclophosphamide monohydrate-with S9 activation, respectively) were added into each well. The plates were incubated at $37 \pm 2{ }^{\circ} \mathrm{C}$ and $5 \% \mathrm{CO}_{2}$ for $3 \mathrm{~h}$. After $3 \mathrm{~h}$ of treatment period, treatment culture media was discarded and cells were washed twice using PBS. Then, $5 \mathrm{~mL}$ of normal culture media was added into each well and plate was incubated at $37 \pm 2{ }^{\circ} \mathrm{C}$ and $5 \pm 1 \% \mathrm{CO}_{2}$ for $21 \mathrm{~h}$. After incubation, the culture media was replaced with $2 \mathrm{~mL}$ of PBS-EDTA. The cells were resuspended to get single cells. The cells suspension was then centrifuged at $1500 \mathrm{rpm}$. The cells pellet were re-suspended with $2 \mathrm{~mL}$ of $\mathrm{KCl}$ hypotonic solution and the cell again were centrifuged at $1500 \mathrm{rpm}$ for $5 \mathrm{~min}$. The cells pellet was fixed using Carnoy's fixative solution. $10 \mu \mathrm{L}$ cells were drop and mounted on pre-warmed frosted slides. The cells were stained using $10 \mu \mathrm{L}$ of $20 \mu \mathrm{g} / \mathrm{mL}$ acridine orange and observed under fluorescence microscope at 20-40× magnification. The images of 2000 cells were captured and scored.

\subsubsection{Statistical Analysis}

SPSS version 16.0 was used for the statistical analysis. Data was analysed using oneway ANOVA and presented in mean and standard error of the mean. Statistical significance was considered with $p$ value $<0.05$.

\subsection{Salmonella typhimurium/Microsome Assay \\ 4.4.1. Bacterial Strains and Metabolic Activation System (S9 Mixture)}

Salmonella typhimurium strains and Escherichia coli strain were purchased from the Molecular Toxicology Incorporated (Moltox), United States. The bacterial strains were stored as frozen stock cultures at $-80^{\circ} \mathrm{C}$. The cultures were preserved with Dimethyl sulfoxide (DMSO) in $1 \mathrm{~mL}$ of broth culture. For metabolic activation system, a cofactorsupplemented post-mitochondrial fraction (S9) was used. The S9 was prepared from the livers of male Sprague Dawley rats induced with phenobarbital and 5,6-benzoflavone.

\subsubsection{Positive Control Mutagen}

2-aminoanthracene (2-AA), Mitomycin C (MMC), ICR-191, Benzo(a)pyrene (BP), Sodium azide (SA) and 2-nitrofluorene (2-NF) were from Sigma-Aldrich, St Louis, MO, United States.

\subsubsection{Mutagenicity Assay}

This study was conducted in accordance with Method 471, Bacterial Reverse Mutation Test (Adopted 21 July 1997), OECD Guideline for testing of chemicals. The Salmonella typhimurium/microsome assay was performed by the standard pre-incubation method with and without addition of an extrinsic metabolic activation system (S9 mixture). The test strains (TA98, TA 100, TA1535, TA1537, and WP2uvrA) were cultured in Nutrient Broth no. 2 and incubated at $37^{\circ} \mathrm{C}$ for $6-9 \mathrm{~h}$. Basically, $100 \mu \mathrm{L}$ of an overnight grown culture (containing approximately $1-2 \times 10^{9}$ bacterial cells per $\mathrm{mL}$ ) was added into culture tubes which contained $100 \mu \mathrm{L}$ of FDAE $(5000,2500,1250,625,313$, and $0 \mu \mathrm{g})$ or standard mutagens (positive control) or sterile distilled water (negative control), and $500 \mu \mathrm{L}$ of phosphate buffer (without S9) or $500 \mu \mathrm{L}$ of S9 mixture. The mixture was incubated for $20 \mathrm{~min}$ at $35 \pm 2{ }^{\circ} \mathrm{C}$ with shaking speed at $100 \mathrm{rpm}$ in the shaker water bath. Two $\mathrm{mL}$ of overlay agar was then added into each culture tubes followed by vigorous mixing and poured on the surface of a minimal agar. The plate was incubated for $48 \mathrm{~h}$ at $37 \pm 2{ }^{\circ} \mathrm{C}$. All plates were then checked for the presence of the background lawn and compared to the negative control group plates. Numbers of revertant bacterial colonies were counted and compared with those in negative and positive control plates. Every experiment was carried out in triplicate. 


\subsubsection{Statistical Analysis}

SPSS version 16.0 was used for the statistical analysis. Data was analysed using one-way ANOVA and presented in mean and standard deviation. Statistical significance was considered with $p$ value $<0.05$.

\section{Conclusions}

Herbal derived medicinal products have become popular to treat several diseases despite the scarce information on the toxicity of certain compounds which may detrimental to human health. In this work, we showed that FDAE was not mutagenic in both in vitro micronucleus and bacterial reverse mutation assays. We suggested that the anti-mutagenic activity could be attributed to the presence of flavonoids with good antioxidant and antigenotoxicity in FDEA. In contrast, DNA damaged was observed when tested using alkaline comet assay towards V79B cells under the in vitro condition. The cellular activities of FDAE may be modulated by a variety of interactions between mutagenic and protective compounds, which may result to a different response pattern. Therefore, further studies using animal model (in vivo) should be conducted to better characterize the mechanism of action and to confirm the genotoxicity effects of FDAE under physiological conditions.

Author Contributions: Conceptualization, H.M., M.H.O., E.N.I.R., S.N.S., F.H.M., L.M.S. and N.A.; methodology, M.H.O., E.N.I.R., S.N.S., F.H.M. and L.M.S.; validation, H.M., M.H.O. and E.N.I.R.; formal analysis, M.H.O., E.N.I.R., S.N.S., F.H.M. and L.M.S.; investigation, M.H.O., E.N.I.R., S.N.S., F.H.M. and L.M.S.; resources, M.H.O., E.N.I.R., S.N.S., F.H.M. and L.M.S.; writing-original draft preparation, H.M. and N.A.; writing-review and editing, N.A. and S.N.S.; visualization, H.M. and M.H.O.; supervision, H.M.; project administration, H.M.; funding acquisition, H.M. All authors have read and agreed to the published version of the manuscript.

Funding: This research was funded by the grant from the Ministry of Health, Malaysia (NMRR14-536-21255). The research has received an approval from the Animal Care and Use Committee, Ministry of Health, Malaysia (ACUC No: ACUC/KKM/02 (2/2017).

Institutional Review Board Statement: Not applicable.

Informed Consent Statement: Not applicable.

Data Availability Statement: Not applicable.

Acknowledgments: The authors gratefully acknowledge the Director General of Health, Ministry of Health, Malaysia and Director of the Institute for Medical Research, National Institutes of Health, Ministry of Health, Malaysia for the permission to publish this paper.

Conflicts of Interest: The authors declare no conflict of interest.

\section{References}

1. Shinde, V.M.; Dhalwal, K.; Potdar, M.; Mahadik, K.R. Application of Quality Control Principles to Herbal Drugs. Int. J. Phytomed. 2009, 1, 4-8.

2. Builders, P.F. Introductory Chapter: Introduction to Herbal Medicine. In Herbal Medicine; IntechOpen: London, UK, 2018.

3. De Smet, P.A. Health Risks of Herbal Remedies. Drug Saf. 1995, 13, 81-93.

4. Roberts, S.M.; James, R.C.; Williams, P.L. Principles of Toxicology: Environmental and Industrial Applications, 3rd ed.; John Wiley \& Sons: New York, NY, USA, 2014.

5. Lansky, E.P.; Paavilainen, H.M. Traditional Herbal Medicines for Modern Times Figs: The Genus Ficus; CRC Press, Taylor \& Francis Group: Boca Raton, FL, USA, 2011; pp. 13-50.

6. Burkill, I.H.; Haniff, M. Malay Village Medicine. Gard. Bull. Straits Settl. 1930, 6, 167-332.

7. Bunawan, H.; Amin, N.M.; Bunawan, S.N.; Baharum, S.N.; Mohd Noor, N. Ficus deltoidea Jack: A Review on Its Phytochemical and Pharmacological Importance. Evid. Based. Complement. Altern. Med. 2014, 2014, 902734.

8. Harborne, J.B.; Williams, C.A. Advances in Flavonoid Research since 1992. Phytochemistry 2000, 55, 481-504.

9. Havsteen, B.H. The Biochemistry and Medical Significance of the Flavonoids. Pharmacol. Ther. 2002, 96, 67-202.

10. Skibola, C.F.; Smith, M.T. Potential Health Impacts of Excessive Flavonoid Intake. Free Radic. Biol. Med. 2000, $29,375-383$.

11. Middleton, E., Jr. Effect of Plant Flavonoids on Immune and Inflammatory Cell Function. Adv. Exp. Med. Biol. 1998, 439, 175-182.

12. Misbah, H.; Aziz, A.A.; Aminudin, N. Antidiabetic and antioxidant properties of Ficus deltoidea fruit extracts and fractions. BMC Complement. Altern. Med. 2013, 13, 118. 
13. Fernandes, L.M.; da Rosa Guterres, Z.; Almeida, I.V.; Vicentini, V.E.P. Genotoxicity and Antigenotoxicity Assessments of the Flavonoid Vitexin by the Drosophila melanogaster Somatic Mutation and Recombination Test. J. Med. Food 2017, 20, 601-609.

14. Anter, J.; Romero-Jiménez, M.; Fernández-Bedmar, Z.; Villatoro-Pulido, M.; Analla, M.; Alonso-Moraga, A.; Muñoz-Serrano, A. Antigenotoxicity, Cytotoxicity, and Apoptosis Induction by Apigenin, Bisabolol, and Protocatechuic Acid. J. Med. Food 2011, 14, 276-283.

15. Eghbaliferiz, S.; Iranshahi, M. Prooxidant Activity of Polyphenols, Flavonoids, Anthocyanins and Carotenoids: Updated Review of Mechanisms and Catalyzing Metals: Prooxidant Activity of Polyphenols and Carotenoids. Phytother. Res. 2016, 30, $1379-1391$.

16. Norrizah, J.S.; Norizan, A.; Sharipah, R.S.A.; Dzulsuhaim, D.; Nurul Hida, M.S. Cytotoxicity Activity and Reproductive Profiles of Male Rats Treated with Methanolic Extracts of Ficus deltoidea. Res. J. Med. Plant 2012, 6, 197-202.

17. Azqueta, A.; Collins, A.R. The Essential Comet Assay: A Comprehensive Guide to Measuring DNA Damage and Repair. Arch. Toxicol. 2013, 87, 949-968.

18. Sakihama, Y.; Cohen, M.F.; Grace, S.C.; Yamasaki, H. Plant Phenolic Antioxidant and Prooxidant Activities: Phenolics-Induced Oxidative Damage Mediated by Metals in Plants. Toxicology 2002, 177, 67-80.

19. Oikawa, S.; Furukawaa, A.; Asada, H.; Hirakawa, K.; Kawanishi, S. Catechins Induce Oxidative Damage to Cellular and Isolated DNA through the Generation of Reactive Oxygen Species. Free Radic. Res. 2003, 37, 881-890.

20. Srinivasan, P.; Vadhanam, M.V.; Arif, J.M.; Gupta, R.C. A rapid screening assay for antioxidant potential of natural and synthetic agents in vitro. Int. J. Oncol. 2002, 20, 983-986.

21. Johnson, M.K.; Loo, G. Effects of Epigallocatechin Gallate and Quercetin on Oxidative Damage to Cellular DNA. Mutat. Res. DNA Repair 2000, 459, 211-218.

22. Sugisawa, A.; Umegaki, K. Physiological Concentrations of (-)-Epigallocatechin-3-O-Gallate (EGCg) Prevent Chromosomal Damage Induced by Reactive Oxygen Species in WIL2-NS Cells. J. Nutr. 2002, 132, 1836-1839.

23. Ogura, R.; Ikeda, N.; Yuki, K.; Morita, O.; Saigo, K.; Blackstock, C.; Nishiyama, N.; Kasamatsu, T. Genotoxicity Studies on Green Tea Catechin. Food Chem. Toxicol. 2008, 46, 2190-2200.

24. Li, D.; Morimoto, K.; Takeshita, T.; Lu, Y. Arsenic induces DNA damage via reactive oxygen species in mammalian cells. Environ. Health Prev. Med. 2001, 6, 27-32.

25. Schwerdtle, T.; Walter, I.; Mackiw, I.; Hartwig, A. Induction of Oxidative DNA Damage by Arsenite and Its Trivalent and Pentavalent Methylated Metabolites in Cultured Human Cells and Isolated DNA. Carcinogenesis 2003, 24, 967-974.

26. Farsi, E.; Shafaei, A.; Hor, S.Y.; Ahamed, M.B.K.; Yam, M.F.; Asmawi, M.Z.; Ismail, Z. Genotoxicity and Acute and Subchronic Toxicity Studies of a Standardized Methanolic Extract of Ficus deltoidea Leaves. Clinics 2013, 68, 865-875.

27. OECD. Test No. 487: In Vitro Mammalian Cell Micronucleus Test; OECD Guideline for Testing of Chemicals; OECD: Paris, France, 2010. 